TSH $\beta$ X1 Splice Variant Expression and D2 Thr92Ala Polymorphism Analysis in Pregnant Women with Thyroid Diseases

Yesica María Rodríguez Cortés, Araceli Amaya Chávez, Magdalena García Fabila, Silvia Jiménez Morales, Carlos Jhovani Pérez Amado, et al.

SN Comprehensive Clinical Medicine

e-ISSN 2523-8973

Volume 1

Number 8

SN Compr. Clin. Med. (2019) 1:590-596 DOI 10.1007/s42399-019-00084-3

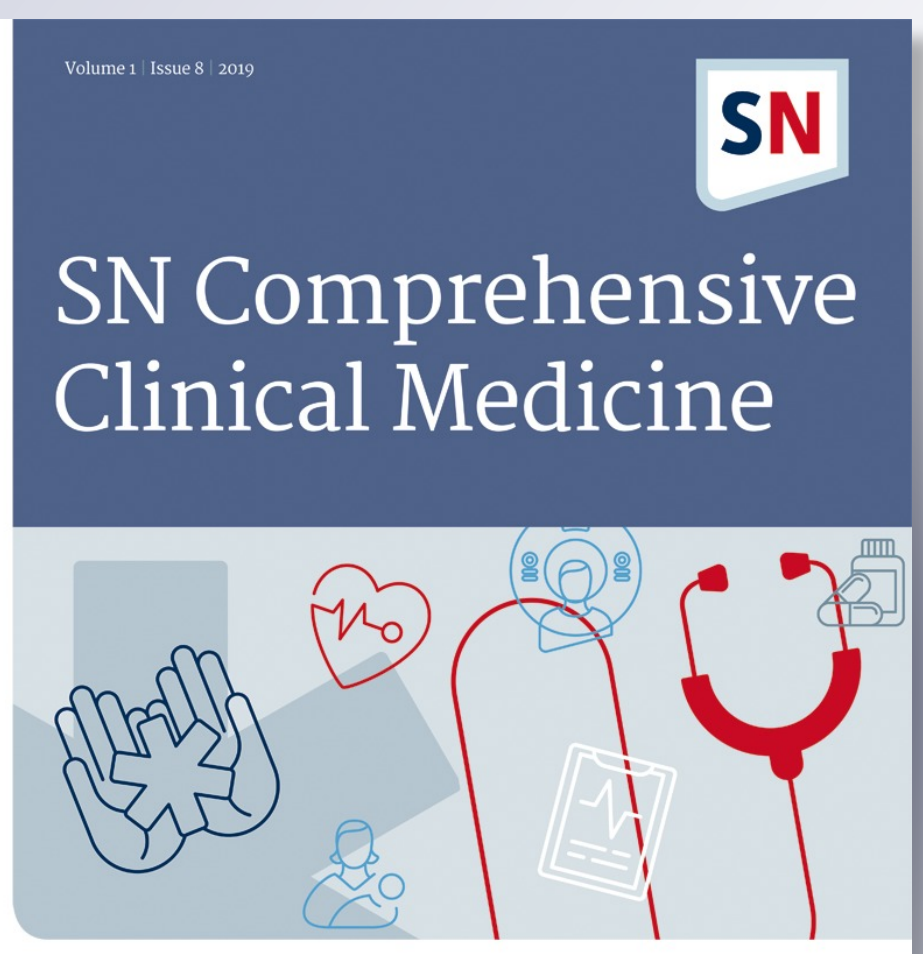

A SPRINGER NATURE journal

算 Springer 
Your article is protected by copyright and all rights are held exclusively by Springer Nature Switzerland AG. This e-offprint is for personal use only and shall not be selfarchived in electronic repositories. If you wish to self-archive your article, please use the accepted manuscript version for posting on your own website. You may further deposit the accepted manuscript version in any repository, provided it is only made publicly available 12 months after official publication or later and provided acknowledgement is given to the original source of publication and a link is inserted to the published article on Springer's website. The link must be accompanied by the following text: "The final publication is available at link.springer.com". 


\title{
TSH $3 X 1$ Splice Variant Expression and D2 Thr92Ala Polymorphism Analysis in Pregnant Women with Thyroid Diseases
}

\author{
Yesica María Rodríguez Cortés ${ }^{1}$ Araceli Amaya Chávez ${ }^{1}$. Magdalena García Fabila ${ }^{1}$ Silvia Jiménez Morales ${ }^{2}$. \\ Carlos Jhovani Pérez Amado $^{3} \cdot$ Hugo Mendieta Zerón ${ }^{4}$ (D)
}

Accepted: 29 May 2019 /Published online: 11 June 2019

(C) Springer Nature Switzerland AG 2019

\begin{abstract}
Thyroid diseases are pathologies that frequently affect pregnant women. The objective was to find out whether the expression of $T S H \beta X 1$ splice variant and D2 Thr92Ala polymorphism in the DIO2 gene are associated with thyroid disease in pregnant women. It was a comparative, prospective clinical, and cross-sectional study. Ninety-two pregnant patients, of which 38 were normothyroid and 54 had thyroid disease, were included. The expression of the TSH $\beta X 1$ splice variant was quantified by realtime PCR and the D2 Thr92Ala (rs225014 CT) polymorphism was genotyped using TaqMan probes. The TSH $\beta X 1$ splice variant was detected in both groups without significant differences in the relative expression. The T allele was associated with the thyroid dysfunction $(\mathrm{OR}=2.117, p=0.0339)$. We confirmed the presence of the predicted $T S H \beta X 1$, and our results suggest that 92Thr (rs225017T) allele is a risk factor to thyroid dysfunction in pregnant women.
\end{abstract}

Keywords Hyperthyroidism · Hypothyroidism · Polymorphism · Pregnancy · TSH $\beta$ X1 · D2 THR92ALA polymorphism

\section{Introduction}

Thyroid diseases are reported in 5 to $10 \%$ of all pregnancies and are associated with serious complications that can contribute to perinatal death and adverse obstetric events $[1,2]$. In pregnancy, there is excessive thyroid stimulation [3] due to physiological changes such as increased thyroid-binding globulin (TBG), increased degradation of T4 to T3 by the inner ring of D3 abundantly expressed in the placenta, amnion, and chorion that generates reverse T3 and the effect of human chorionic gonadotropin (hCG). By sharing alpha chain with $\mathrm{TSH}$, hCG generates a false stimulation of receptors increasing the levels of $\mathrm{T} 3$ and $\mathrm{T} 4$, doing pregnancy a favorable scenario for thyroid dysfunctions [4].

On the other hand, deiodinase 2 (DIO2) is a selenoenzyme responsible for the deiodination of $\mathrm{T} 4$ to $\mathrm{T} 3$, which makes it crucial for the proper functioning of thyroid hormones. D2 is produced by the DIO2 gene (NC_000014.9), which is located on chromosome 14 in the long arm position 14q24.3 [5]. A change of the $\mathrm{T}$ allele by $\mathrm{C}$ generates an amino acid coding alanine instead of threonine in position 92, which makes the protein differ from the canonical structure. In 2017, Wouters et al. proposed that the presence of the Thr92Ala (rs225014 $\mathrm{CT}$ ) polymorphism of $\mathrm{DIO} 2$ influences enzymatic function

This article is part of the Topical Collection on Medicine

Hugo Mendieta Zerón

drmendietaz@yahoo.com

Yesica María Rodríguez Cortés

jmariarodriguez@unicolmayor.edu.co

Araceli Amaya Chávez

amayacha8789@gmail.com

Magdalena García Fabila

mmgafa@yahoo.com.mx

Silvia Jiménez Morales

sjimenez@inmegen.gob.mx
Carlos Jhovani Pérez Amado

jhamado24@gmail.com

1 Autonomous University of the State of Mexico, Toluca, Mexico

2 National Institute of Genomic Medicine, Mexico, Mexico

3 Biochemical Science Program, National Autonomous University of Mexico, Mexico, Mexico

4 Faculty of Medicine, Autonomous University of the State of Mexico and Ciprés Grupo Médico S.C. (CGM), Mexico, Mexico 
and its presence is thought to predict a favorable response in a combination therapy of levothyroxine (LT4) and T3 [6]. Furthermore, the Ala92Ala genotype was reported to be related with a reduction in the placental activity of D2, which could worsen gestational complications [7].

In addition to the above, TSH variants have been proven to be related with thyroid dysfunction, osteoprotection in patients with hyperthyroidism $(T S H-\beta v)$, or with immune processes (R55G variant) [8-10]. In this line of knowledge, it has been predicted by automated computational analysis a Homo sapiens TSH beta transcript variant X1 (TSH $\beta X 1)$ (XM_011542065.2) derived from a genomic sequence (NC_000001.11) using the Gnomon gene prediction method [11]. The predicted variant belongs to the BioProject: PRJNA168, related to the GenBank project: PRJNA31257.

The aim of this study was to describe the allele frequency of the Thr92Ala in pregnant women with or without thyroid disease and to confirm the $T S H \beta X 1$ splice variant expression in this population.

\section{Material and Methods}

\section{Setting}

This was a clinical, comparative, prospective, and transversal study. Pregnant women aged 18-44 years old, attended at the "Mónica Pretelini Sáenz" Maternal-Perinatal Hospital (HMPMPS), Health Institute of the State of Mexico (ISEM), Toluca, Mexico, were invited to participate.

Two groups were conformed: (A) Normothyroid pregnant women (NT) and (B) patients with a thyroid disease named hypothyroidism or hyperthyroidism (TD). Patients with other chronic diseases were excluded and those whose clinical follow-up was lost or that in the puerperium had to be treated in the obstetric intensive care unit were eliminated from the study, besides the samples that were not suitable for genetic analysis were eliminated too.

\section{Sample Calculation}

The sample was calculated with Eq. 1.

$n_{0}=\frac{2\left(Z_{a}+Z_{\beta}\right)^{2} S^{2}}{d^{2}}$

where $n_{0}$ : necessary size of the sample, $S$ : standard deviation, $d$ : difference to find, $Z$ alpha $=1.96, Z$ beta: 0.482 . The relative units (UR) of gene expression were taken into account as measures, accepting an alpha risk of 0.05 and a beta risk of 0.2 in a bilateral contrast, obtaining a sample size of 48 subjects per group, to detect an equal or greater difference at $4 \mathrm{RU}$ with a standard deviation of 7.

\section{Sociodemographic Information}

All the participants answered a questionnaire that included demographic information such as name, age and address, obstetric data (number of pregnancies, deliveries, cesareans, and abortions), and familiar thyroid disease background. The anthropometric and laboratory data (weight, height, body mass index (BMI), glucose, creatinine, triglycerides, total cholesterol, and TSH) from all the patients were obtained from the clinical files.

\section{Blood Samples}

Peripheral blood samples ( 2 tubes of $5 \mathrm{~mL}$, a total blood tube with EDTA anticoagulant for the genetic analysis, and a dry tube for the determination of the hormone TSH) were collected by venipuncture in the arm. All samples were stored at $80{ }^{\circ} \mathrm{C}$ until the analysis.

\section{TSH Quantification}

TSH measurements were performed using the ELISA technique (diagnostics A) at the Research Laboratory of Ciprés Grupo Médico S.C. (CGM).

\section{Identification of the D2 Thr92Ala Polymorphism}

\section{DNA Extraction}

The DNA was extracted in the Laboratory of Genetics, Faculty of Medicine, UAEMex, using the kit QIAmp DNA Mini and Blood kit from Qiagen DNA, (Cat no./ID: 51106). The genetic material purity and integrity were measured with the Nanodrop 1000 and was stored at $-20{ }^{\circ} \mathrm{C}$ until genotyping. DNA integrity was verified by E-Gel gels in the E-Gel iBase and E-Gel Safe Imager (Invitrogen).

\section{Genotyping}

The genotyping was carried out with a total concentration of $30 \mathrm{ng} / \mu \mathrm{l}$ in each reaction well, using $0.06 \mu \mathrm{l}$ of the rs 225014 (Thr92Ala) primers and probes contained in Human Custom TaqMan Genotyping Assay C_15819951_10, $2.5 \mu \mathrm{l}$ of Master Mix, $2.44 \mu \mathrm{l}$ of water and $5 \mu \mathrm{l}$ of DNA (all from Thermo Fisher Scientific, Waltham, MA, USA). Then, a conventional PCR was performed in a GeneAmp System 9700 thermal cycler using the following cycling program: denaturation of: $50^{\circ} \mathrm{C} 2 \mathrm{~min}$, and $95^{\circ} \mathrm{C} 10 \mathrm{~min}$, followed by 40 cycles of $94{ }^{\circ} \mathrm{C} 15 \mathrm{~s}$, and 40 cycles $60{ }^{\circ} \mathrm{C} 1 \mathrm{~min}$; to finish at $4{ }^{\circ} \mathrm{C}$ $7 \mathrm{~min}$. At the end of the PCR program, the amplified plate was taken to the QuantStudio 3 Real-Time PCR System 
genotyping equipment using TaqMan probes to process each sample of the patients. Genotyping data were validated by sequencing three samples from each genotype as we previously reported [12] and using the following primers: $5^{\prime}$ CTGGCTCGTGAAAGGAGGTCAA 3' and 3'CCAATTCC AGTGTGGTGCATGT 5' [13].

\section{TSH $\beta X 1$ Expression Analysis}

\section{RNA Isolation}

The RNA was extracted in the Laboratory of Genetics, Faculty of Medicine, UAEMex, using the Norgen's Total RNA Purification Kit (Norgen Biotek Corp.). The purity and integrity of total RNA were assessed using a NanoPhotometer (Implen GmbH, Germany).

\section{Real-Time PCR}

In the Research Laboratory of Ciprés Grupo Médico S.C. (CGM), the TSH $\beta X 1$ expression was determined by the realtime PCR technique in a PrimeQ (Techne, UK) equipment. The primers used were synthesized at the Synthesis and DNA Sequencing Unit of the National Autonomous University of Mexico (UNAM), Institute of Biotechnology (Cuernavaca, Morelos, Mexico). The SYBR Green RNA to Ct 1 step Kit (Cat. number 4389986) was used with the following oligonucleotides: GADPH (House keeping gene): 5'CTTGGTAT CGTGGAAGGACTC 3', 3'GTAGAGGCAGGGAT GATGTTCT 5' and TSH $\beta X 1$ : 5'TGTGGGCAAGCGAT GTCTTTT 3', 3'GATGGTTAGGCAATAAGCACACT 5'. The reaction was done with a final volume of $50 \mu \mathrm{l}$, the primers' concentration were of $200 \mathrm{nM}$ and the samples of $100 \mathrm{ng}$. Cycling was programmed in the following way: retrotranscription step $\left(48^{\circ} \mathrm{C} 30 \mathrm{~min} \times 1\right.$ cycle), enzyme activation $\left(95^{\circ} \mathrm{C} 10 \mathrm{~min} \times 1\right.$ cycle), denaturation $\left(95^{\circ} \mathrm{C} 15 \mathrm{~s} \times 40\right.$ cycles), alignment $\left(59^{\circ} \mathrm{C} 30 \mathrm{~s} \times 40\right.$ cycles $)$, extension $\left(60^{\circ} \mathrm{C}\right.$ $30 \mathrm{~s} \times 40$ cycles $)$, and melting curve $\left(72{ }^{\circ} \mathrm{C} 1 \mathrm{~min} \times 61 \mathrm{cy}-\right.$ cles). The fold change in TSHBX1 splice variant was normalized against $G A D P H$ and then compared with the controls through the $2^{-\Delta \Delta \mathrm{CT}}$ method.

\section{Statistical Analysis}

Hardy-Weinberg equilibrium (HWE) was evaluated to the Thr92Ala genotypes by using Finetti program (https://ihg. gsf.de/cgi-bin/hw/hwa2.pl). Continuous data were expressed as means \pm standard deviation (SD). Statistical analysis was performed using the Mann-Whitney $U$ test after performing the Levene test. The normality hypothesis was tested using the Kolmogorov-Smirnov test. Odds ratio (OR) test was used to compare the $T S H B X 1$ splice variant positive identification, D2 Thr92Ala genotypes, and alleles with the presence/absence of thyroid disease. Statistical significance was tested at the $p \leq 0$. 05 level using SPSS ver. 23.0 software (IBM Corp., Armonk, NY, USA).

\section{Ethics}

All participants gave their informed consent and both the Research Committee and the Ethics on Research Committee of the HMPMPS approved the protocol (code: 2016-09-481). All procedures were performed in accordance with the Declaration of Helsinki and the General Health Law in Mexico.

\section{Results}

\section{Sociodemographic and Anthropometric Data}

Of all the 96 samples collected, four were excluded because their clinical follow-up was lost; obtaining an $N=92$, of which 54 had thyroid dysfunction (cases) and 38 were NT (controls). The initial proportion of both groups changed because in the analysis of TSH serum levels, it was found that more patients had altered hormone through the follow-up period. The description of the study population is depicted in Table 1 .

There were no differences in the number of abortions among groups, which led to infer that in the patients analyzed,

Table 1 General description of study population

\begin{tabular}{|c|c|c|c|c|c|}
\hline \multirow[t]{2}{*}{ Group } & \multirow{2}{*}{$\begin{array}{l}\text { Age (years) } \\
\text { mean } \pm \text { SD }\end{array}$} & \multicolumn{2}{|c|}{ Gestational antecedent } & \multirow{2}{*}{$\begin{array}{l}\text { Previous abortions } \\
N(\%)\end{array}$} & \multirow{2}{*}{$\begin{array}{l}\text { Family history of thyroid } \\
\text { dysfunction } \\
N(\%)\end{array}$} \\
\hline & & $\begin{array}{l}\text { Primigravid } \\
N(\%)\end{array}$ & $>1$ pregnancies $N(\%)$ & & \\
\hline Control group $(N=38)$ & $27 \pm 8$ & $15(39.47)$ & $23(60.52)$ & $11(28.94)$ & $5(13.15)$ \\
\hline $\begin{array}{l}\text { Thyroid disfunction } \\
(N=54)\end{array}$ & $28 \pm 5$ & $22(40.7)$ & $32(59.25)$ & $14(20.37)$ & $19(35.18)$ \\
\hline $\begin{array}{l}\text { Total } \\
(N=92)\end{array}$ & $28 \pm 7$ & $37(40.21)$ & $55(59.78)$ & $25(27.17)$ & $24(26.08)$ \\
\hline
\end{tabular}


the thyroid pathology was not influencing the gestational losses. Regarding the relationship of the health status of the patients with the presence or absence of a family history of thyroid disease, it was observed that while $86 \%(n=33)$ of the patients in the NT group had no family history, by contrast, $35.18 \%(n=19)$ of the patients with a thyroid dysfunction had a family member with a thyroid-related disease. A significant $p<0.05$ was obtained when looking for this relationship, evidencing that there is a connection between family history and thyroid dysfunction. The descriptive statistics of the groups are observed in Table 2.

In terms of BMI, most of the patients belong to the category of overweight and obesity. However, there was no significant difference between the two groups. Regarding blood pressure, only one patient in each study group presented hypertension. In addition, 13 different dosage types of levothyroxine or thiamazol were registered and only one patient was untreated.

\section{TSH Screening}

Taking into account the reference values for TSH per trimester [14], seven patients were reassigned to the group of thyroid diseases because their serum TSH levels exceeded the limits allowed in the specific gestational trimester.

\section{D2 Thr92Ala Allele Frequency}

The genotypes were in HWE, showing the next distribution: $40(48.2 \%)$ patients presented the CC genotype, of which 22 (55\%) had no thyroid disease, while $18(45 \%)$ were from the group with thyroid dysfunction. For the CT genotype, which was found in $33(39.8 \%)$ patients, the opposite happened that the majority of the $(n=23,69.7 \%)$ patients with thyroid dysfunction had it and $10(30.3 \%)$ were from the NT group. The
TT genotype was present in $10(12 \%)$ patients who, in their majority $(n=7,70 \%)$, were patients with thyroid dysfunction. In summary, the $\mathrm{T}$ allele was the most common in cases with thyroid dysfunction in comparison with NT $(\mathrm{OR}=2.117, p=$ 0.0339) (Table 3). Comparisons between TSH levels and each genotype were performed without finding significant differences.

\section{TSH $\beta$ X1 Expression}

This TSHBX1 splice variant was present in $14(25.92 \%)$ of the cases and in $13(34.21 \%)$ of the controls. Eleven cDNA samples were not adequate for expression analysis. When performing the OR analysis between the state of health and the presence/absence of the gene transcript, there was not confirmation of a significant statistical difference (OR 0.6731, $95 \%$ CI $0.2722-1.6643, p=0.3914)$. Otherwise, the fold change was of 3.33 in the TD group vs ND group for the relative expression of this splice variant.

\section{Discussion}

The thyroid diseases do not have a unique origin; genetic, endogenous, and environmental factors are involved [15, 16]. It has been previously published that a relationship between obesity and hypothyroidism in which leptin levels intervene and in which TSH is directly responsible for weight gain [17]. Perhaps, a population without these basic problems would have seen a significant difference between the two study groups.

Of particular concern is that not suffering a thyroid disease in pregnancy does not exonerate a healthy patient from having complications in postpartum due to the thyroid gland. In fact,
Table 2 Anthropometric, clinical characteristics, and biochemical data of the population

\begin{tabular}{llll}
\hline Variable & $\begin{array}{l}\text { Total study } \\
\text { population }\end{array}$ & $\begin{array}{l}\text { Thyroid disfunction group } \\
(n=54)\end{array}$ & $\begin{array}{l}\text { Normothyroid group } \\
(n=38)\end{array}$ \\
\hline Weight $(\mathrm{kg})$ & $70.0( \pm 14.3)$ & $70.1( \pm 14.7)$ & $69.9( \pm 14.1)$ \\
Height $(\mathrm{cm})$ & $155( \pm 0.0)$ & $1.55( \pm 0.06)$ & $155( \pm 0.05)$ \\
$\mathrm{SBP}(\mathrm{mmHg})$ & $108.4( \pm 11.8)$ & $109.3( \pm 13.4)$ & $107.3( \pm 9.5)$ \\
$\mathrm{DBP}(\mathrm{mmHg})$ & $68.3( \pm 10.3)$ & $69.2( \pm 11.9)$ & $67.2( \pm 7.9)$ \\
$\mathrm{BMI}\left(\mathrm{kg} / \mathrm{m}^{2}\right)$ & $28.9( \pm 5.0)$ & $29.01( \pm 5.3)$ & $28.8( \pm 4.6)$ \\
$\mathrm{Glucose}(\mathrm{mg} / \mathrm{dL})$ & $80.0( \pm 16.0)$ & $79( \pm 18)$ & $81.3( \pm 13.3)$ \\
$\mathrm{TC}(\mathrm{mg} / \mathrm{dL})$ & $205( \pm 54.7)$ & $216.3( \pm 62.0)$ & $188.5( \pm 37.9)$ \\
$\mathrm{TG}(\mathrm{mg} / \mathrm{dL})$ & $213.4( \pm 94.9)$ & $225.3( \pm 105.1)$ & $198.4( \pm 80.2)$ \\
$\mathrm{Hb}(\mathrm{g} / \mathrm{dL})$ & $13.2( \pm 1.5)$ & $12.9( \pm 1.7)$ & $13.5( \pm 1.1)$ \\
$\mathrm{Creatinine}$ & $0.6( \pm 0.1)$ & $0.60( \pm 0.1)$ & $0.58( \pm 0.1)$ \\
$(\mathrm{mg} / \mathrm{dL})$ & & & \\
\hline
\end{tabular}

$B M I$ body mass index, $D B P$ diastolic blood pressure, $H b$ hemoglobin, $S B P$ systolic blood pressure, $T C$ total cholesterol, $T G$ triglycerides 
Table 3 Genotype and allele distribution per group

\begin{tabular}{|c|c|c|c|c|}
\hline $\begin{array}{l}\text { Thr92Ala rs225014 } \\
\text { CT }\end{array}$ & $\begin{array}{l}\text { No thyroid disease } n \\
(\%)\end{array}$ & $\begin{array}{l}\text { Thyroid disease } n \\
\text { (\%) }\end{array}$ & OR IC (95\%) & $\begin{array}{l}p \\
\text { value }\end{array}$ \\
\hline Genotype & $N=35$ & $N=48$ & & \\
\hline $\begin{array}{l}\text { Ala92Ala (CC) } \\
\text { Thr92Ala (TC) }\end{array}$ & $\begin{array}{l}22(62.8) \\
10(28.6)\end{array}$ & $\begin{array}{l}18(37.5) \\
23(47.9)\end{array}$ & & 0.07 \\
\hline Thr92AThr (TT) & $3(8.6)$ & $7(14.6)$ & & \\
\hline $\mathrm{CC}$ vs TC & & & 2.811 [1.067-7.409] & 0.0343 \\
\hline CC vs TT & & & $2.852[0.643-12.642]$ & 0.1573 \\
\hline \multicolumn{5}{|l|}{ Allele } \\
\hline $\mathrm{C}$ & $54(73.3)$ & $59(61.5)$ & & \\
\hline $\mathrm{T}$ & $16(26.7)$ & $37(38.5)$ & $\begin{array}{l}2.1165 \\
\quad[1.0585-4.2322]\end{array}$ & 0.0339 \\
\hline
\end{tabular}

$99 \%$ of genotyping (low DNA quality in one sample)
5 to $18 \%$ of healthy patients present in the first year a postpartum thyroiditis $[18,19]$. What is clear from this study is the relationship between the family history of thyroid disease and the health status of our patients. The previous thing verifies the great influence of the genetic background in the presentation of the disease. In this case, there are many genes involved in the development of these diseases, which can follow a pattern in terms of anomalies over several generations. In addition, the most frequent pathology at the thyroid level was clinical hypothyroidism, which is consistent with the epidemiological data regarding the incidence of the disease [20].

For instance, DIO2 and TSH have been implicated in the thyroid disease development. Polymorphisms in DIO2 could interfere in the expression level or the activity of this enzyme, potentially altering the metabolism of thyroid hormones [7, 21]. On this field, comparing the Thr92Thr homozygous and Thr92Ala heterozygous genotypes, the D2 activity has been found to decline among Ala92Ala homozygous [22]. In fact, the D2 Ala92Ala genotype is related with a reduction in the placental activity of D2, which could worsen gestational complications [7]. Studying pregnant women with or without thyroid disease, we identified the $\mathrm{Thr} 92$ (T) allele as a risk factor to thyroid disease in pregnant women. So far, most of the studies attribute the $\mathrm{C}$ allele as the diseased genotype since it has been associated with drug resistance, lower T3 values, and complications with diabetes [23-25]. However, other group reported the $\mathrm{C}$ allele as more common in healthy patients suggesting that it is a low-risk factor for the disease [26] which is in accordance with our data. A differential distribution of these alleles between ethnic groups have been reported, being the $\mathrm{C}$ allele the less frequent in populations with Asian and European ancestry than subjects with Amerindian background [27]. These contradictory results have to be elucidated; however, we cannot discard that sample sizes and the genetic background could bias our results.
An important issue to take into account is the identification of possible risk factors in order to improve the prevention methods in pregnancies' complications. According to the 2017 Guidelines of the American Thyroid Association (ATA) for the Diagnosis and Management of Thyroid Disease During Pregnancy and the Postpartum, if any of the following risk factors are identified, testing for serum TSH is recommended: (1) a history of hypothyroidism/hyperthyroidism or current symptoms/signs of thyroid dysfunction, (2) known thyroid antibody positivity or presence of a goiter, (3) history of head or neck radiation or prior thyroid surgery, (4) age $>30$ years, (5) type 1 diabetes or other autoimmune disorders, (6) history of pregnancy loss, preterm delivery, or infertility, (7) multiple prior pregnancies $(\geq 2)$, (8) family history of autoimmune thyroid disease or thyroid dysfunction, (9) morbid obesity (BMI $\geq 40 \mathrm{~kg} / \mathrm{m}^{2}$ ), (10) use of amiodarone or lithium, or recent administration of iodinated radiologic contrast, and (11) residing in an area of known moderate to severe iodine insufficiency [14].

From the above mentioned risk factors, autoimmunity in our population seems to be one of the most important factors, since we must take into account that the percentage of mothers with AITD and with an affected daughter is $13 \%$ [28], but the challenge we face is to detect this autoimmunity process before pregnancy. Even more, the results of this survey support the usefulness of the identification of polymorphisms and genetic variants that increase the risk of developing thyroid disease during pregnancy.

Our study constitutes a characterization of the Mexican population and also confirms a role for a strict thyroid function monitoring during pregnancy [4]. In case of institutional budget limitations, TSH must be measured in the first trimester to all pregnant women with a strong family history of thyroid disease, over 30 years of age, with autoimmune diseases, morbid obesity, or who have received radiation in head and neck [29]. 
Finally, in this initial approach, the higher fold change in the expression of the TSH $\beta X 1$ splice variant in the TD group makes suppose an implication of this variant to develop a thyroid dysfunction. Notwithstanding, the information is not conclusive and needs further corroboration.

At this stage, the presence of the TSH $\beta X 1$ splice variant in the analyzed population opens the possibility of a new study, in which the role of the interactome in thyroid dysfunctions can be evidenced, to see if the association of the resulting protein with other molecules is involved with the disease. In other words, the studies have to establish if the protein-protein interactions are affecting the cellular response [30].

Limitations of our study include the relatively low number of patients, even for our institution, attributed to the rate of acceptance of the patients to participate into any study but at the same time, it is valuable to see ethical recommendations avoiding coercion in such an important decision. Secondly, the possibility of stratification bias cannot be ruled out in our sample due to the treatment of the patients. It is also a limitation the scarce information of the TSH $\beta X 1$ splice variant thus restricting the conclusions of its positive expression. Further, the TSH serum increments in the NT group during the following period made us lose the initial equal distribution of the groups, forcing us to use nonparametric tests in the analysis.

\section{Conclusions}

Our data suggests that the allele $\mathrm{T}$ of Ala92Ala is associated with thyroid disease. To the best of our knowledge, this is the first study showing expression of the predicted TSH $\beta X 1$ splice variant in human pregnant women, being an example of the certainty of the informatics sequence genome prediction.

Acknowledgments The authors thank MSc. Cristian F. Layton Tovar for his help in the TSH quantification and to all the clinical staff of the Maternal-Fetal Medicine Service of the HMPMPS for their support to develop this project.

Funding This project was partially funded by Ciprés Grupo Médico, Grant 2017-07.

\section{Compliance with Ethical Standards}

Conflict of Interest The authors declare that they have no conflict of interest.

Ethical Approval The Ethics on Research Committee of the HMPMPS approved the protocol (code: 2016-09-481).

Informed Consent All participants gave their informed consent.

\section{References}

1. González-Velázquez A, Ávalos-Guerrero Á, Ramírez-Montiel ML, et al. Incidencia de patología tiroidea durante el embarazo. Méd Sur. 2003;20:11-6.

2. Nijkamp JW, Korteweg FJ, Groen H, Timmer A, van den Berg G, Bossuyt PM, et al. Thyroid function testing in women who had a stillbirth. Clin Endocrinol. 2016;85:291-928. https://doi.org/10. $1111 /$ cen.13002.

3. Nazarpour S, Tehrani FR, Simbar M, et al. Thyroid and pregnancy in Tehran, Iran: objectives and study protocol. Int J Endocrinol Metab. 2016;14:e33477. https://doi.org/10.5812/ijem.33477.

4. Leung AM. Thyroid function in pregnancy. J Trace Elem Med Biol. 2012;26:137-40. https://doi.org/10.1016/j.jtemb.2012.03.004.

5. Araki O, Murakami M, Morimura T, et al. Assignment of type II iodothyronine deiodinase gene (DIO2) to human chromosome band $14 \mathrm{q} 24.2->\mathrm{q} 24.3$ by in situ hybridization. Cytogenet Cell Genet. 1999;84:73-4. https://doi.org/10.1159/000015218.

6. Wouters HJCM, van Loon HCM, van der Klauw MM, Elderson MF, Slagter SN, Kobold AM, et al. No effect of the Thr92Ala polymorphism of deiodinase- 2 on thyroid hormone parameters, health-related quality of life, and cognitive functioning in a large population-based cohort study. Thyroid. 2017;27:147-55. https:// doi.org/10.1089/thy.2016.0199.

7. Dora JM, Wajner SM, Costa JD, Pinto Ribeiro RV, Leiria LB, Lopes MG, et al. Type 2 deiodinase Thr92Ala polymorphism is associated with disrupted placental activity but not with dysglycemia or adverse gestational outcomes: a genetic association study. Fertil Steril. 2014;101:833-40. https://doi.org/10.1016/j. fertnstert.2013.11.018.

8. Moreno-Navarrete JM, Moreno M, Ortega F, Xifra G, Hong S, Asara JM, et al. TSHB mRNA is linked to cholesterol metabolism in adipose tissue. FASEB J. 2017;31:4482-91. https://doi.org/10. 1096/fj.201700161R.

9. Baliram R, Latif R, Zaidi M, Davies TF. Expanding the role of thyroid-stimulating hormone in skeletal physiology. Front Endocrinol (Lausanne). 2017;8:252. https://doi.org/10.3389/ fendo.2017.00252.

10. Pappa T, Johannesen J, Scherberg N, Torrent M, Dumitrescu A, Refetoff S. A TSH $\beta$ variant with impaired immunoreactivity but intact biological activity and its clinical implications. Thyroid. 2015;25:869-76. https://doi.org/10.1089/thy.2015.0096.

11. PREDICTED: Homo sapiens thyroid stimulating hormone beta (TSHB), transcript variant X1, mRNA. Available from: https:// www.ncbi.nlm.nih.gov/nuccore/XM 011542065.2. Accessed 30 March 2019.

12. Mendieta Zerón H, Jiménez Rosales A, Pérez Amado CJ, et al. FOXE1 mutation screening in a case with cleft lip, hypothyroidism and thyroid carcinoma: a new syndrome? Case. Rep Genet. 2017;2017:6390545. https://doi.org/10.1155/2017/6390545.

13. Luo M, Zhou XH, Zou T, Keyim K, Dong LM. Type II deiodinase polymorphisms and serum thyroid hormone levels in patients with mild cognitive impairment. Genet Mol Res. 2015;14:5407-16. https://doi.org/10.4238/2015.May.22.10.

14. Alexander EK, Pearce EN, Brent GA, Brown RS, Chen H, Dosiou C, et al. 2017 Guidelines of the American Thyroid Association for the Diagnosis and Management of Thyroid Disease during pregnancy and the postpartum. Thyroid. 2017;27:315-89. https://doi. org/10.1089/thy.2016.0457.

15. Janssen BG, Saenen ND, Roels HA, Madhloum N, Gyselaers W, Lefebvre W, et al. Fetal thyroid function, birth weight, and in utero exposure to fine particle air pollution: a birth cohort study. Environ Health Perspect. 2017;125:699-705. https://doi.org/10.1289/EHP508.

16. Kahr MK, Antony KM, DelBeccaro M, Hu M, Aagaard KM, Suter MA. Increasing maternal obesity is associated with alterations in 
both maternal and neonatal thyroid hormone levels. Clin Endocrinol. 2016;84:551-7. https://doi.org/10.1111/cen.12974.

17. Sanyal D, Raychaudhuri M. Review article hypothyroidism and obesity: an intriguing link. Indian J Endocrinol Metab. 2016;20: 554-7. https://doi.org/10.4103/2230-8210.183454.

18. Alemu A, Terefe B, Abebe M, Biadgo B. Thyroid hormone dysfunction during pregnancy: a review. Int J Reprod Biomed (Yazd). 2016;14:677-86.

19. Pedersen C, Leserman J, Garcia N, Stansbury M, Meltzer-Brody S, Johnson J. Late pregnancy thyroid-binding globulin predicts perinatal depression. Psychoneuroendocrinology. 2016;65:84-93. https://doi.org/10.1016/j.psyneuen.2015.12.010.

20. Panicker V. Genetics of thyroid function and disease. Clin Biochem Rev. 2011;32:165-75.

21. Leiria LB, Dora JM, Wajner SM, Estivalet AAF, Crispim D, Maia AL. The rs225017 polymorphism in the 3UTR of the human DIO2 gene is associated with increased insulin resistance. PLoS One. 2014;9(8):e103960. https://doi.org/10.1371/journal.pone.0103960.

22. Canani LH, Capp C, Dora JM, Meyer ELS, Wagner MS, Harney $\mathrm{JW}$, et al. The type 2 deiodinase $\mathrm{A} / \mathrm{G}$ (Thr92Ala) polymorphism is associated with decreased enzyme velocity and increased insulin resistance in patients with type 2 diabetes mellitus. J Clin Endocrinol Metab. 2005;90:3472-8. https://doi.org/10.1210/jc. 2004-1977.

23. Carlé A, Laurberg P. Hypothyroid patients encoding combined MCT10 and DIO2 gene polymorphisms may prefer L-T3 + L-T4 combination treatment - data using a blind, randomized, clinical study. Eur Thyroid J. 2017;6:143-51. https://doi.org/10.1159/ 000469709 .

24. Castagna MG, Dentice M, Cantara S, Ambrosio R, Maino F, Porcelli T, et al. DIO2 Thr92Ala reduces deiodinase-2 activity and serum-T3 levels in thyroid-deficient patients. J Clin Endocrinol Metab. 2017;102:1623-30. https://doi.org/10.1210/jc. 2016-2587.
25. Yalakanti D, Dolia PB. Association of Type II 5' monodeiodinase Thr92Ala single nucleotide gene polymorphisms and circulating thyroid hormones among type 2 diabetes mellitus patients. Indian J Clin Biochem. 2016;31:152-61. https://doi.org/10.1007/s12291015-0518-9.

26. Gałecka E, Talarowska M, Orzechowska A, Górski P, Bieńkiewicz $\mathrm{M}$, Szemraj J. Association of the DIO2 gene single nucleotide polymorphisms with recurrent depressive disorder. Acta Biochim Pol. 2015;62:297-302. https://doi.org/10.18388/abp.2015 1002.

27. Rajeevan H, Osier MV, Cheung KH, Deng H, Druskin L, Heinzen R, et al. ALFRED: the Alelle FREquency database. Update. Nucleic Acids Res. 2003;31:270-1.

28. Conzuelo Rodríguez G, Mendieta Zerón H. Familial autoimmune thyroid disease and PTPN-22. Med Glas (Zenica). 2015;12:151-6. https://doi.org/10.17392/803-15.

29. Stagnaro-Green A, Abalovich M, Alexander E, et al. American Thyroid Association taskforce on thyroid disease during pregnancy and postpartum. American Thyroid Association taskforce on thyroid disease during pregnancy and postpartum. Guidelines of the American Thyroid Association for the diagnosis and management of thyroid disease during pregnancy and postpartum. Thyroid. 2011;21:1081-125. https://doi.org/10.1089/thy.2011.0087.

30. Huttlin EL, Ting L, Bruckner RJ, Gebreab F, Gygi MP, Szpyt J, et al. The BioPlex network: a systematic exploration of the human Interactome. Cell. 2015;162:425-40. https://doi.org/10.1016/j.cell. 2015.06.043.

Publisher's Note Springer Nature remains neutral with regard to jurisdictional claims in published maps and institutional affiliations. 